\title{
Dietary and Ergogenic Supplementation to Improve Elite Soccer Players' Performance
}

\author{
Haniel Fernandes ${ }^{a, b}, c$ \\ ${ }^{a}$ Nutrition Department, Estácio de Sá College, Fortaleza, Brazil; ' São Gabriel da Palha College, Nutrition, Metabolism \\ and Physiology in Sport, Espírito Santo, Brazil; 'São Gabriel da Palha College, Clinical and Functional Nutrition, \\ Espírito Santo, Brazil
}

\section{Keywords}

Soccer performance · Ergogenic supplementation - Dietary supplementation · Sport nutrition

\begin{abstract}
Background: Soccer is an extremely competitive sport, where the most match important moments can be defined in detail. Use of ergogenic supplements can be crucial to improve the performance of a high-performance athlete. Therefore, knowing which ergogenic supplements are important for soccer players can be an interesting strategy to maintain high level in this sport until final and decisive moments of the match. In addition, other supplements, such as dietary supplements, have been studied and increasingly referenced in the scientific literature. But, what if ergogenic supplements were combined with dietary supplements? This review brings some recommendations to improve performance of soccer athletes on the field through dietary and/ or ergogenic supplements that can be used simultaneously. Summary: Soccer is a competitive sport, where the match important moments can be defined in detail. Thus, use of ergogenic supplements covered in this review can improve performance of elite soccer players maintaining high level in the match until final moments, such as creatine $3-5 \mathrm{~g} \mathrm{day}^{-1}$, caffeine $3-6 \mathrm{mg} \mathrm{kg}^{-1}$ BW around 60 min before the match,
\end{abstract}

sodium bicarbonate $0.1-0.4 \mathrm{~g} \mathrm{~kg}^{-1} \mathrm{BW}$ starting from 30 to $180 \mathrm{~min}$ before the match, $\beta$-alanine 3.2 and $6.4 \mathrm{~g}$ day ${ }^{-1}$ provided in the sustained-release tablets divided into 4 times a day, and nitrate-rich beetroot juice $60 \mathrm{~g}$ in $200 \mathrm{~mL}$ of water ( $6 \mathrm{mmol} \mathrm{NO}^{-} \mathrm{L}$ ) around $120 \mathrm{~min}$ before match or training, including a combination possible with taurine $50 \mathrm{mg} \mathrm{kg}^{-1}$ BW day $^{-1}$, citrulline 1.2-3.4 $\mathrm{g}_{\text {day }}{ }^{-1}$, and arginine $1.2-6 \mathrm{~g}$ day $^{-1}$. Key Messages: Soccer athletes can combine ergogenic and dietary supplements to improve their performance on the field. The ergogenic and dietary supplements used in a scientifically recommended dose did not demonstrate relevant side effects. The use of various evidence-based supplements can add up to further improvement in the performance of the elite soccer players.

(c) 2021 S. Karger AG, Basel

\section{Introduction}

Soccer has characteristics of short and long duration and low and high intensity with intermittent exercises of prolonged duration [1] involving sprints, changes of direction, jumps, accelerations, and decelerations, besides walking or light running [2]. The greatest loss of performance of the athletes can happen in match's final moments, exactly in the final $10 \mathrm{~min}$ of the second half [2], karger@karger.com

(c) 2021 S. Karger AG, Basel

www.karger.com/anm

Karger"
Correspondence to:

Haniel Fernandes, haniel_fernandes@hotmail.com 
Table 1. Recommendation of dietary and ergogenic supplements to improve the performance of elite soccer players

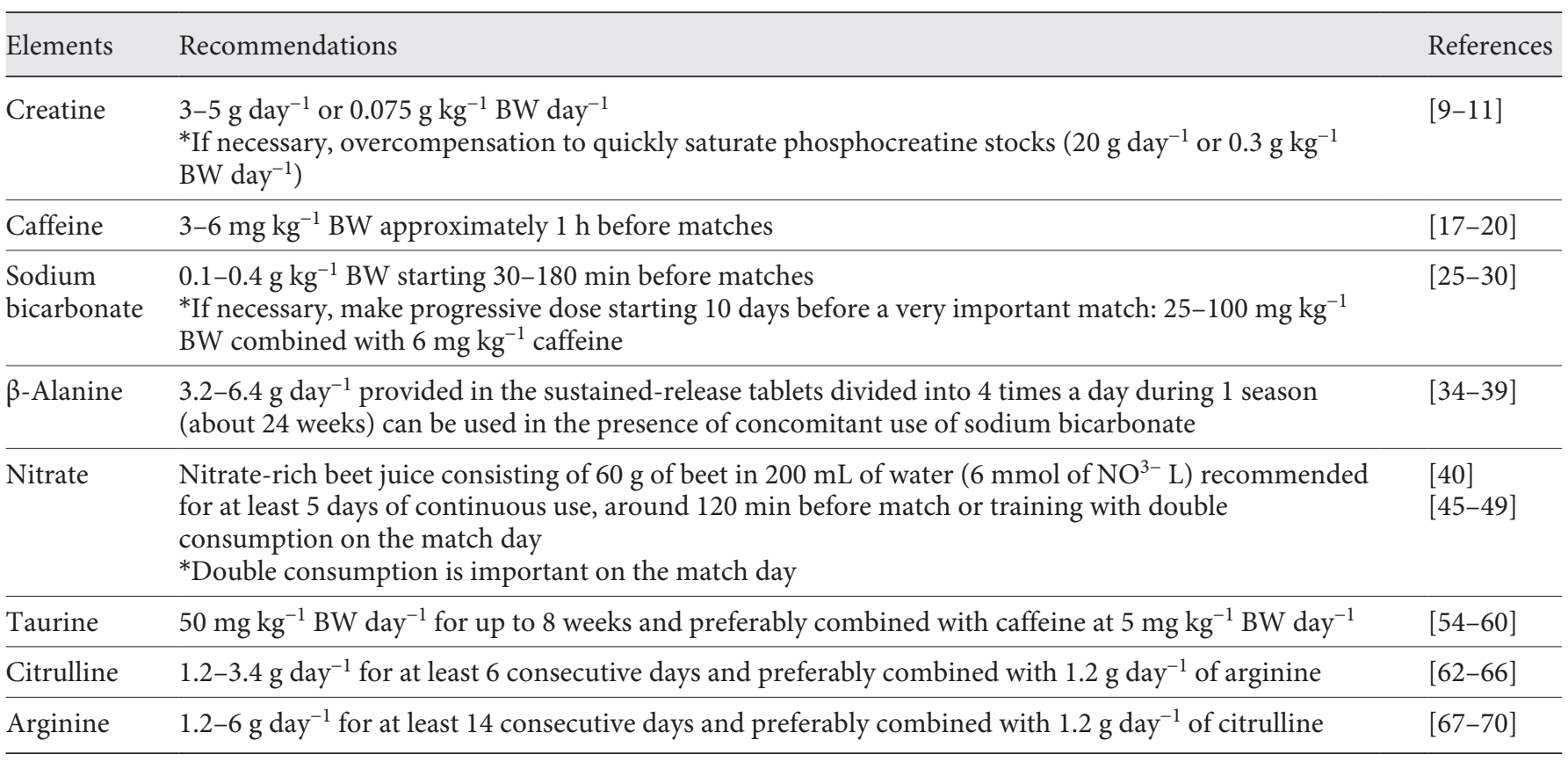

highlighting the importance of ergogenic supplementation to optimize their performance. Recently, the Academy of Nutrition and Dietetics, Dietitians of Canada (DC), and the American College of Sports Medicine (ACSM) provided a guideline prepared mainly by their members with the main sports supplements to improve the athletes' performance [3].

A recent study in the English Premier League evaluated the caloric expenditure and total caloric intake of soccer players at 5 training days and 2 days of games, and as a result, total energy intake was higher in match days $\left(3,789 \pm 532 \mathrm{kcal}\right.$ and $61.1 \pm 11.4 \mathrm{kcal} \mathrm{kg}^{-1}$ fat-free mass $)$ compared to training days $(2,956 \pm 374 \mathrm{kcal}$ and $45.2 \pm$ $9.3 \mathrm{kcal} \mathrm{kg}^{-1}$ of fat-free mass) [4]. Therefore, there is caution of greater caloric intake for training and games. So, amounts or dosages of ergogenic and dietary supplements provided to athletes during these periods must be established. As more intense travel periods are common in elite soccer (i.e., 1-3 matches per week) [5], adjusting their supplementation can be a great alternative to help maintain or improve their performance during training, matches, and travels. Therefore, the purpose of this review is to provide recommendations for ergogenic supplement prescription including dietary supplements to improve elite soccer players' performance.

\section{Methods}

The research that supports this work was carried out through PubMed, Science Direct, and Google Scholar databases using the following keywords: "creatine," "beta-alanine," "beet juice," "nitrate," "arginine," "taurine," "citrulline," "sodium bicarbonate," "performance," "soccer," and "elite soccer players." The search was completed without being confined to any specific years, with results being included up to November 30, 2020, inclusive. The compilation of studies was evaluated by the author without obeying preestablished inclusion or exclusion criteria, and they only belonged to the work context. Of the 277 articles similar to the descriptors selected that were identified in the course of the literature search, only 38 fulfilled the purpose of review and are placed in Table 1, providing the reader a summary direct of review clearly and objectively.

\section{Creatine}

Creatine is popular among soccer players [6], synthesized from the amino acids arginine, glycine, and methionine and stored about $95 \%$ in the skeletal muscle and can be found in the free form or linked to a phosphate molecule (phosphocreatine) [7]. During exercise, the breakdown of muscle glycogen by glycogenolysis will contribute approximately $50 \%$ of ATP production, with about $48 \%$ of phosphocreatine and $2 \%$ of muscle ATP stock [8]. The soccer has high-intensity and short-duration activities [2], where creatine supplementation is interesting. In addition, creatine supplementation acts on the fluid level of skeletal muscle cells, as demonstrated by a double-blind, controlled work with $0.3 \mathrm{~g} \mathrm{~kg}^{-1}$ of body weight (BW) of creatine supplementation during 7 days involving 13 soccer players [9] promoting ATP resynthesis and subsequent improvements in the performance of soccer players. 
A double-blind, controlled study with 19 soccer players supplemented with creatine $\left(0.3 \mathrm{~g} \mathrm{~kg}^{-1} \mathrm{BW} \mathrm{day}{ }^{-1}\right)$ for 14 days concluded significant improvements in power tests using $30 \mathrm{~s}$ of the Wingate anaerobic test (WAnT) [10]. In another randomized, doubleblind, controlled study, parallel groups containing 14 Brazilian elite soccer players, who did not use creatine, were supplemented with $20 \mathrm{~g} \mathrm{day}^{-1}$ for 1 week divided into 4 equal doses to enhance phosphocreatine concentration (overcompensation), followed by daily doses of $5 \mathrm{~g}$ during 6 weeks. Soccer-specific physical tests were performed, and significant improvements in jumping performance were obtained [11]. In summary, the creatine recommendation for professional soccer players consists of 3-5 $\mathrm{g} \mathrm{day}^{-1}$ or $0.075 \mathrm{~g} \mathrm{~kg}^{-1} \mathrm{BW}$ day ${ }^{-1}[8]$.

\section{Caffeine}

Caffeine supplementation is recognized by the International Olympic Committee and the International Sports Nutrition Society [12]; it improves performance by attenuating the potassium output of muscle cells [13], has alert effect due to antagonism of caffeine to adenosine receptors in the central nervous system [14], and improves the use of muscle glycogen during exercise [15]. Therefore, an athlete will have a longer time until fatigue, helping effects if there is a desensitization in the $24 \mathrm{~h}$ before the competition (abstaining from caffeine) [16].

A controlled, crossover, randomized study with 12 soccer players evaluated $6 \mathrm{mg} \mathrm{kg}^{-1} \mathrm{BW}$ caffeine $1 \mathrm{~h}$ before the test and found improvements in time to hit a penalty and performance in the countermovement jump [17]. Two hundred fifty milliliters of a drink containing caffeine $\left(3 \mathrm{mg} \mathrm{kg}^{-1} \mathrm{BW}\right)$ and $7 \%$ carbohydrates was tested on 18 soccer players and was found to induce significant improvements in the vertical jump tests performed after a soccer match [18]. In addition, in 2 meta-analyses with $>60$ studies, the effectiveness of caffeine for endurance was proven, and its additional ergogenic effect on the athlete's performance can reach $>3 \%$ $[19,20]$. In summary, the caffeine supplementation recommended for professional soccer players consists of 3-6 mg kg-1 BW around $60 \mathrm{~min}$ before the match, if possible with no caffeine products in the $24 \mathrm{~h}$ before the match.

\section{Sodium Bicarbonate}

During the high-intensity exercise, a soccer game for example, there is an increase in blood lactate concentration, a product of the glycolytic pathway used to provide energy and maintain the intensity of the exercise $[21,22]$; to keep the amount of lactate in the skeletal muscle high for a longer period, supplementation with sodium bicarbonate $\left(\mathrm{NaHCO}_{3}\right)$ has been used, a buffering agent that attenuates the decline in muscle $\mathrm{pH}$, decreasing acidity and improving performance $[22,23]$. However, it contains risks of gastrointestinal problems and metabolic alkalosis due to dose and time of ingestion, respectively [24].

A study supplemented 16 men with 3 doses of sodium bicarbonate, $0.1 \mathrm{~g} \mathrm{~kg}^{-1} \mathrm{BW}, 0.2 \mathrm{~g} \mathrm{~kg}^{-1} \mathrm{BW}$, and $0.3 \mathrm{~g} \mathrm{~kg}^{-1} \mathrm{BW}$, and found, respectively, increased blood $\mathrm{NaHCO} 3$ concentrations per dose $\left(+2.0-5,+5.1-8.1\right.$, and $\left.+6.0-2.3 \mathrm{mmol} \mathrm{L}^{-1}\right)$ and dose over time (30-150, 40-165, and 75-180 min) [25]. A study of 13 men tested $0.4 \mathrm{~g} \mathrm{~kg}^{-1} \mathrm{BW}$ of $\mathrm{NaHCO}_{3}$ in intermittent Yo-Yo running tests and obtained 14\% improvement in performance and $7 \%$ decrease in the perceived exertion rate [26]. Another study with 11 participants examined supplementation with $0.4 \mathrm{~g} \mathrm{~kg}^{-1} \mathrm{BW}$ of $\mathrm{NaHCO}_{3}$ in the running-based anaerobic sprint test (RAST) and concluded significant improvements in total amount of work with lower blood pH [27]. After ingesting $0.4 \mathrm{~g} \mathrm{~kg}^{-1} \mathrm{BW}$ of $\mathrm{NaHCO}_{3}$, 10 soccer players were evaluated with Yo-Yo tests and got better $(70 \%)$ in high-speed running $\left(17-21 \mathrm{~km} \mathrm{~h}^{-1}\right)$ [28]. The progressive dose on the eve of the competition was used in a study with 58 athletes supplemented with $\mathrm{NaHCO}_{3}$ for 10 consecutive days with a progressive dose regimen $\left(25 \mathrm{mg} \mathrm{kg}^{-1} \mathrm{BW}\right.$ on days 1 and $2,50 \mathrm{mg}$ $\mathrm{kg}^{-1} \mathrm{BW}$ on days 3,4 , and $5,75 \mathrm{mg} \mathrm{kg}^{-1} \mathrm{BW}$ on days 6 and 7 , and $100 \mathrm{mg} \mathrm{kg}^{-1} \mathrm{BW}$ on days 8,9 , and 10); it resulted in a significant improvement in peak power time on Wingate tests [29]. A doubleblind, crossover, randomized, controlled study using 7-day washout tested effects of combining $6 \mathrm{mg} \mathrm{kg}^{-1}$ caffeine with $0.3 \mathrm{mg} \mathrm{kg}^{-1}$ day $^{-1}$ sodium bicarbonate in 8 athletes and concluded that combining caffeine with $\mathrm{NaHCO}_{3}$ can increase performance in aerobic exercises [30]. Maybe this methodology can be applied to elite soccer players when they want greater performance, as in finals and/ or very decisive matches. In summary, the sodium bicarbonate supplement recommended for professional soccer players consists of $0.1-0.4 \mathrm{~g} \mathrm{~kg}^{-1} \mathrm{BW}$ starting from 30 to $180 \mathrm{~min}$ before the match, and a progressive dose regimen can be used with doses $25-100 \mathrm{mg}$ $\mathrm{kg}^{-1} \mathrm{BW}$ combined with $6 \mathrm{mg} \mathrm{kg}^{-1}$ caffeine.

\section{Beta-Alanine}

Muscle carnosine is a dipeptide formed by the combination of the amino acids $\beta$-alanine and L-histidine and participates in the buffering of muscle cells by accepting protons during the induced $\mathrm{pH}$ increase where your limiting factor is the availability of $\beta$-alanine [31]. As the muscle is unable to synthesize carnosine precursors, $\beta$-alanine supplementation induces an increase in intramuscular carnosine content increasing the buffering capacity [32]. A systematic review and meta-analysis involving 40 studies with $\beta$-alanine supplementation concluded that this practice can have an ergogenic effect on performance depending on the athlete's modality [33].

A randomized, double-blind, placebo-controlled trial tested $\beta$-alanine supplementation in 16 soccer athletes with $4.8 \mathrm{~g} \mathrm{day}^{-1}$ (approximately $84 \mathrm{mg} \mathrm{kg}^{-1} \mathrm{BW}$ ) divided into 6 doses every $2 \mathrm{~h}$ during 6 weeks and obtained significant improvements in jumping performance, repeated sprint, and resistance compared to the control group [34]. Seventeen soccer players were recruited for a double-blind, controlled study and supplemented with $\beta$-alanine (3.2 $\mathrm{g} \mathrm{d}^{-1}$ ) provided in the form of $800 \mathrm{mg}$ sustained-release tablets for 12 weeks (at the beginning and middle of the season) and obtained significant improvements in Yo-Yo performance compared to placebo [35]. The total daily recommendation remains between 3.2 and $6.4 \mathrm{~g} \mathrm{day}^{-1}$ provided in the sustained-release tablets divided from 2 to 6 for at least 4 weeks of continuous use up to 24 weeks [36-38]. A double-blind, crossover, controlled study evaluated 20 athletes to test the effect of beta-alanine with or without sodium bicarbonate on total time performance and concluded significant changes when the combination was used [39]. In summary, the $\beta$-alanine supplementation recommended for professional soccer players consists of 3.2 and $6.4 \mathrm{~g} \mathrm{day}^{-1}$ provided in the sustainedrelease tablets divided into 4 times a day during 1 season (about 24 weeks) which can be used in the presence of concomitant use of sodium bicarbonate.

\section{Nitrate}

Dietary supplementation of nitrate $\left(\mathrm{NO}^{-}\right)$through beet juice induces an increase in the concentration of nitrite $\left(\mathrm{NO}^{2-}\right)$ in plas- 
ma [40] subsequently increasing the production of nitric oxide (NO) [41]. The high bioavailability of nitric oxide increases release of calcium $\left(\mathrm{Ca}^{2+}\right)$ improving contractile function of the skeletal muscle [42] and helping recovery of phosphocreatine reserves, which prevents depletion during repeated efforts and improves release and reuptake of calcium in the sarcoplasmic reticulum [43, 44]. However, nitrate metabolism to nitric oxide requires oral cavity bacteria [41] and peak in the blood occurs $2-3 \mathrm{~h}$ after ingestion [45], so the athletes cannot use antibacterial mouthwash or toothpaste before consuming beet juice [40].

A double-blind, crossover, randomized study with 36 male players tested supplementation with beet juice at $6 \mathrm{mmol} \mathrm{NO}^{3-}$ for a high-performance team sport for 5 days using Yo-Yo tests, and the results showed significantly better improvement $(+4 \%)$ in the athletes' performance [46]. Another randomized, crossover, double-blind, placebo-controlled study using $70 \mathrm{~mL}$ of beet juice on 15 participants found significantly increased peak and average potency and blood lactate levels [47]. Fourteen male recreational team sports players were assigned to a double-blind, randomized, crossover project to consume $490 \mathrm{~mL}$ of nitrate-rich beet juice ( 6 mmol NO${ }^{3-}$ ) and nitrate-low beet juice (placebo), which showed significant increase $(+4,2 \%)$ in Yo-Yo test performance [48]. A double-blind, crossover, randomized, parallel design study involving 29 athletes compared 14 days with supplementation of nitraterich beet juice versus placebo (nitrate-poor beet juice), where the 2 groups consumed extradose nitrate-rich beet juice $2 \mathrm{~h}$ before the experiment, and concluded that just the group with nitrate-rich beet juice for chronic use (14 days) showed reduced testing time and increased potency [49]. In summary, supplementation with nitrate-rich beet juice consisting of $60 \mathrm{~g}$ of beet in $200 \mathrm{~mL}$ of water $\left(6 \mathrm{mmol}\right.$ of $\left.\mathrm{NO}^{3-} \mathrm{L}\right)$ is recommended for at least 5 days of continuous use, around 120 min before match or training with double consumption on the match day.

\section{Taurine}

Taurine supplementation aids human maximal voluntary muscle contraction [50], reduces muscle damage, and brings additional benefits in hepatic metabolism $[51,52]$. Actually, its use for improving soccer performance was not much studied in the scientific literature. However, a meta-analysis, involving 10 prospective studies, demonstrated possible significant effects on the performance of endurance athletes [53]. Another study, with a randomized, crossover, and controlled model, evaluated the supplementation of $5 \mathrm{~g} \mathrm{day}^{-1}$ of taurine for 1 week in 20 athletes and concluded improvements in reaction time plays [54]. Another crossover, randomized, controlled model study evaluated $3 \mathrm{~g} \mathrm{day}^{-1}$ of taurine for 8 weeks in 14 professional swimming athletes and concluded a possible increase in lactate production together with a possible additional effect on anaerobic lactic metabolism [55]. Besides these, other studies with young strength athletes found that taurine can mitigate muscle pain and induce positive effects on muscle contraction $[56,57]$.

But, taurine supplementation showed improved results with caffeine combination, as shown in a crossover, randomized, double-blind, controlled study with 7 soccer players that tested $5 \mathrm{mg}$ $\mathrm{kg}^{-1} \mathrm{BW} \mathrm{day}^{-1}$ of caffeine combined with $50 \mathrm{mg} \mathrm{kg}^{-1} \mathrm{BW}$ day ${ }^{-1}$ of taurine. This combination improved the rate of intrasprint fatigue, heart rate, and the rate of blood pressure produced [58]. Another double-blind, acute, crossover study involving 16 active men tested the effects of 3 and $6 \mathrm{~g}$ day $^{-1}$ taurine doses in moderate fasting running training protocol and concluded lower respiratory coefficients with use of taurine [59]. Twelve recreational active men participated in a crossover, randomized, controlled, double-blind study to test the effects of taurine on performance on a cycle ergometer with $50 \mathrm{mg} \mathrm{kg}^{-1} \mathrm{BW}$ day $^{-1}$ taurine dose for 7 days and concluded a significant improvement on time to exhaustion, peak power, and critical power, in addition to increasing the biochemical lactate levels numerically [60]. In summary, the taurine supplementation recommended for professional soccer players consists of $50 \mathrm{mg} \mathrm{kg}^{-1} \mathrm{BW}$ day ${ }^{-1}$ for up to 8 weeks and preferably combined with caffeine at $5 \mathrm{mg} \mathrm{kg}^{-1} \mathrm{BW} \mathrm{day}^{-1}$.

\section{Citrulline}

Citrulline supplementation is involved in arginine metabolism; in the kidneys, citrulline is converted into arginine up to the endothelial vessel wall where endothelial nitric oxide synthase converts arginine to nitric oxide and citrulline to start the cascade of using $\mathrm{Ca}^{2+}$ from the sarcoplasma to the sarcoplasmic reticulum, increasing muscle relaxation [61]. A double-blind, controlled, randomized study with an acute dose $500 \mathrm{~mL}$ of watermelon juice enriched with citrulline $(3.4 \mathrm{~g})$ for 21 runners decreased perception of muscle pain 24-72 h after running [62].

A 3-week, double-blind, randomized, crossover, controlled study with 22 trained cyclists tested citrulline supplementation $\left(2.4 \mathrm{~g} \mathrm{day}^{-1}\right)$ for 7 days using time tests and found significant reductions in total test time and significant increases at power [63]. A double-blind, randomized, controlled study with 20 professional soccer players tested combined supplementation with $1.2 \mathrm{~g}$ arginine and $1.2 \mathrm{~g}$ citrulline for 6 days and found additional benefits in performance and subjective perceptions effort [64]. Ten healthy, trained men participated in a crossover, randomized, doubleblind, placebo-controlled study to test the acute effects of $12 \mathrm{~g}$ citrulline in high-performance tests on 3 occasions separated by 7 days (washout) concluding significant improvement in frequency cardiac output but not in performance [65]. Another randomized, double-blind, placebo-controlled, crossover, counterbalanced study included 12 men with $8 \mathrm{~g}$ citrulline acutely and found no improvement in strength training performance [66]. In summary, citrulline supplementation recommended for professional soccer players consists of 1.2-3.4 $\mathrm{g} \mathrm{day}^{-1}$ at least for 6 consecutive days and preferably combined with $1.2 \mathrm{~g} \mathrm{day}^{-1}$ of arginine.

\section{Arginine}

All ingested arginine is degraded mainly in the gastrointestinal tract and liver through the enzyme arginase, which is inhibited by citrulline ingestion, so coingestion of these amino acids can increase circulating arginine concentrations [64]. A controlled, randomized, double-blind study involving 19 soccer players tested $0.15 \mathrm{~g} \mathrm{~kg}^{-1}$ arginine acute dose in RAST and concluded that there was no significant improvement [67]. That is, acute supplementation of $3 \mathrm{~g}$ arginine was not able to induce improvements in vasodilation or performance [68].

However, a double-blind, controlled, randomized study tested the effectiveness of $2 \mathrm{~g}$ arginine supplementation on performance of 56 soccer players during 45 days and found significant improvements in maximum oxygen consumption (VO2max) with subsequent performance increase [69]. Twenty-eight soccer players were selected and supplemented with $6 \mathrm{~g}$ arginine during 14 days, and their performance in the RAST protocol on six 35-m consecutive sprints with $10 \mathrm{~s}$ of active rest was tested. It was concluded that 
dose influenced the body's lactate levels and reduced the damage after workout in the muscle by decreasing lactate dehydrogenase [70]. In summary, the arginine supplementation recommended for professional soccer players consists of $1.2-6 \mathrm{~g} \mathrm{day}^{-1}$ for at least 14 consecutive days and preferably combined with $1.2 \mathrm{~g} \mathrm{day}^{-1}$ of citrulline.

\section{Conclusion}

Elite soccer players have nutritional weapons to improve performance on the field through dietary or ergogenic supplements such as taurine, citrulline, and arginine and ergogenic supplements such as creatine, caffeine, sodium bicarbonate, beet juice (nitrate), and beta-alanine. Besides everything, some combinations have been demonstrated to improve performance such as arginine with citrulline, caffeine with sodium bicarbonate, beta-alanine with sodium bicarbonate, and taurine with caffeine. This way, additional benefits of mixtures containing ergogenic supplements and dietary supplements can be welcomed for elite soccer players. In summary, Table 1 presents a direct and elaborate outline of dietary and ergogenic supplements with evidence-based recommendations to improve the performance of elite soccer players that can be combined.

Although the results reported in this review show a trend toward improvement in elite soccer players' performance, we cannot confirm that taking all supplements mentioned here will bring additional benefits over use of 1 or 2 dietary and ergogenic supplements. Thus randomized, crossover, controlled clinical studies using a compilation of dietary and ergogenic supplements would be needed to assess whether taking all these supplements would be better than taking 1 or 2 in synergy.

\section{Conflict of Interest Statement}

The author has no conflicts of interest to declare.

\section{Funding Sources}

No funding was received for this study.

\section{References}

1 Strudwick T. "Soccer Science," Hum. Kinects; 2016. Available from: https://books.google. com.br/books?hl=pt-BR\& $\quad$ lr $=\&$ $\mathrm{id}=\mathrm{rvF} 6 \mathrm{DwAAQBAJ} \& \quad$ oi=fnd $\& \quad \mathrm{pg}=\mathrm{PR} 1 \&$ ots=wsd2alZdX7\& sig=per-pApntjmvyn6LgEEAHsxmsKI\& redir_esc $=\mathrm{y} \# \mathrm{v}=$ onepage $\&$ $\mathrm{q} \& \mathrm{f}=$ false.

2 Mohr M, Krustrup P, Bangsbo J. Match performance of high-standard soccer players with special reference to development of fatigue. J Sports Sci. 2003;21(7):519-28.

3 Van Itallie TB, Sinisterra L, Stare FJ. Nutrition and athletic performance. J Am Med Assoc. 2016;162(12):1120-6.

4 Anderson L, Orme P, Naughton RJ, Close GL, Milsom J, Rydings D, et al. "Energy intake and expenditure of professional soccer players of the english premier league: evidence of carbohydrate periodization." Int J Sport Nutr Exerc Metab. 2017;27(3):128-38.

5 Anderson L, Orme P, Di Michele R, Close GL, Morgans R, Drust B, et al. Quantification of training load during one-, two- and threegame week schedules in professional soccer players from the English Premier League: implications for carbohydrate periodisation. J Sports Sci. 2016;34(13):1250-9.

6 Tscholl P, Junge A, Dvorak J. The use of medication and nutritional supplements during FIFA World Cups 2002 and 2006. Br J Sports Med. 2008;42(9):725-30.
7 Nicolay K, Wyss M, Brdiczka D, Wallimann T, Eppenberger HM. "Intracellular compartmentation, structure and function of creatine kinase isoenzymes in tissues with high and fluctuating energy demands: the 'phosphocreatine circuit' for cellular energy homeostasis. Biochem J. 2015;281(1):21-40.

8 Miny K, Burrowes J, Jidovtseff B. Interest of creatine supplementation in soccer. Sci Sports. 2017;32(2):61-72.

9 Deminice R, Rosa FT, Pfrimer K, Ferrioli E, Jordao AA, Freitas E. Creatine supplementation increases total body water in soccer players: a deuterium oxide dilution study. Int J Sports Med. 2015;37(2):149-53.

10 Yáñez-Silva A, Buzzachera CF, Piçarro IDC, Januario RSB, Ferreira LHB, McAnulty SR, et al. Effect of low dose, short-term creatine supplementation on muscle power output in elite youth soccer players. J Int Soc Sports Nutr. 2017;14(1):5-8.

11 Claudino JG, Mezêncio B, Amaral S, Zanetti $\mathrm{V}$, Benatti F, Roschel H, et al. Creatine monohydrate supplementation on lower-limb muscle power in Brazilian elite soccer players. J Int Soc Sports Nutr. 2014;11(1):32.-6

12 Maughan RJ, Burke LM, Dvorak J, LarsonMeyer DE, Peeling P, Phillips SM, et al. IOC consensus statement: dietary supplements and the high-performance athlete. Br J Sports Med. 2018;52(7):439-55.
13 McDaniel LW, McIntire K, Streitz C, Jackson A, Gaudet L. The effects of caffeine on athletic performance. Coll Teach Methods Styles J. 2016;6(1):33

14 Lazarus M, Shen HY, Cherasse Y, Qu WM, Huang ZL, Bass CE, et al. Arousal effect of caffeine depends on adenosine $\mathrm{A} 2 \mathrm{~A}$ receptors in the shell of the nucleus accumbens. J Neurosci. 2011;31(27):10067-75.

15 Loureiro LMR, Reis CEG, Da Costa THM. Effects of coffee components on muscle glycogen recovery: a systematic review. Int J Sport Nutr Exerc Metab. 2018;28(3):284-93.

16 Sen C, Bagchi D, Nair N. Nutrition and enhanced sports performance. 2nd ed. Elsevier; 2019.

17 Foskett A, Ali A, Gant N. Caffeine enhances cognitive function and skill performance during simulated soccer activity. Int J Sport Nutr Exerc Metab. 2009;19(4):410-23.

18 Guttierres APM, Natali AJ, Alfenas Rde CG, Marins JCB. Efeito ergogênico de uma bebida esportiva cafeinada sobre a performance em testes de habilidades específicas do futebol. Rev Bras Med Esporte. 2009; 15(6):450-4.

19 Shen JG, Brooks MB, Cincotta J, Manjourides JD. Establishing a relationship between the effect of caffeine and duration of endurance athletic time trial events: a systematic review and meta-analysis. J Sci Med Sport. 2019; 22(2):232-8
Dietary and Ergogenic Supplementation Improves Soccer Players' Performance 
20 Southward K, Rutherfurd-Markwick KJ, Ali A. "The effect of acute caffeine ingestion on endurance performance: a systematic review and meta-analysis. Sport Med. 2018;48(8): 1913-28.

21 Green RW. Impact of active and passive recovery on metabolic measures. Br J Sports Med. 2008;19(3):173-4.

22 Schwesig R, Schulze S, ReinhardtL, Laudner KG, Delank KS, HermassiS. "Differences in player position running velocity at lactate thresholds among male professional German soccer players" 2019.

23 Chycki J, Golas A, Halz M, Maszczyk A, Toborek M, Zajac A. Chronic ingestion of sodium and potassium bicarbonate, with potassium, magnesium and calcium citrate improves anaerobic performance in elite soccer players. Nutrients. 2018;10(11):1610.

24 Kahle LE, Kelly PV, Eliot KA, Weiss EP. Acute sodium bicarbonate loading has negligible effects on resting and exercise blood pressure but causes gastrointestinal distress. Nutr Res. 2013;33(6):479-86.

25 Jones RL, Stellingwerff T, Artioli GG, Saunders B, Cooper S, Sale C. Dose-response of sodium bicarbonate ingestion highlights individuality in time course of blood analyte responses. Int J Sport Nutr Exerc Metab. 2016; 26(5):445-53.

26 Krustrup P, Ermidis G, Mohr M. Sodium bicarbonate intake improves high-intensity intermittent exercise performance in trained young men. J Int Soc Sports Nutr. 2015;12(1): 25-7.

27 Miller P, Robinson AL, Sparks SA, Bridge CA Bentley DJ, McNaughton LR. The effects of novel ingestion of sodium bicarbonate on repeated sprint ability. J Strength Cond Res. 2016;30(2):561-8.

28 Mohr M. Effect of sodium bicarbonate ingestion on measures of football performance: with reference to the impact of training status. Frit. 2015;62:102-22.

29 Durkalec-Michalski K, Zawieja EE, Podgórski T, Zawieja BE, Michałowska P, Łoniewski I, et al. The effect of a new sodium bicarbonate loading regimen on anaerobic capacity and wrestling performance. Nutrients. 2018; 10(6):697.

30 Rezaei S, Akbari K, Gahreman DE, Sarshin A, Tabben M, Kaviani M, et al. Caffeine and sodium bicarbonate supplementation alone or together improve karate performance. J Int Soc Sports Nutr. 2019;16(1):44-8.

31 Saunders B, DE Salles Painelli V, DE Oliveira LF, DA Eira Silva V, DA Silva RP, Riani L, et al. Twenty-four weeks of $\beta$-alanine supplementation on carnosine content, related genes, and exercise. Med Sci Sports Exerc. 2017;49(5):896-906.

32 Blancquaert L, Everaert I, Derave W. Beta-alanine supplementation, muscle carnosine and exercise performance. Curr Opin Clin Nutr Metab Care. 2015;18(1):63-70.
33 Dolan E, Elliott-Sale K, Artioli GG, Swinton PA, Roschel H, Sale Craig FACSM, et al. $\beta$-alanine supplementation to improve exercise capacity and performance. Med Sci Sport Exerc. 2017;49(5):84

34 Rosas F, Ramírez-Campillo R, Martínez C, Caniuqueo A, Cañas-Jamet R, McCrudden E, et al. Effects of plyometric training and betaalanine supplementation on maximal-intensity exercise and endurance in female soccer players. J Hum Kinet. 2017;58(1):99-109.

35 Saunders B, Sunderland C, Harris RC, Sale C. $\beta$-alanine supplementation improves YoYo intermittent recovery test performance. J Int Soc Sports Nutr. 2012;9(5):39.

36 Quesnele JJ, Laframboise MA, Wong JJ, Kim $\mathrm{P}$, Wells GD. The effects of beta-alanine supplementation on performance: a systematic review of the literature. Int J Sport Nutr Exerc Metab. 2014;24(1):14-27.

37 Saunders B, Franchi M, de Oliveira LF, da Eira Silva V, da Silva RP, de Salles Painelli V, et al. 24 -week $\beta$-alanine ingestion does not affect muscle taurine or clinical blood parameters in healthy males. Eur J Nutr. 2020;59(1):57-65.

38 Saunders B, Franchi M, Oliveira LF, Painelli VS, Silva VE, Silva RP, et al. Chronic (24 weeks) beta-alanine supplementation does not affect muscle taurine or blood clinical chemistry. Med Sci Sport Exerc. 2018;50(5S): 590.

39 Hobson RM, Harris RC, Martin D, Smith P, Macklin B, Gualano B, et al. Effect of betaalanine with and without sodium bicarbonate on 2,000-m rowing performance. Int J Sport Nutr Exerc Metab. 2013;23(5):480-7.

40 Van der Avoort CMT, Van Loon LJC, Hopman MTE, Verdijk LB. Increasing vegetable intake to obtain the health promoting and ergogenic effects of dietary nitrate. Eur J Clin Nutr. 2018;72(11):1485-9.

41 Domínguez R, Maté-Muñoz JL, Cuenca E, García-Fernández P, Mata-Ordoñez F, Lozano-Estevan MC, et al. Effects of beetroot juice supplementation on intermittent high-intensity exercise efforts. J Int Soc Sports Nutr. 2018;15:2.

42 Coggan AR, Peterson LR. Dietary nitrate enhances the contractile properties of human skeletal muscle. Exerc Sport Sci Rev. 2018; 46(4):254-61.

43 Domínguez R, Cuenca E, Maté-Muñoz JL, García-Fernández P, Serra-Paya N, Estevan $\mathrm{MC}$, et al. Effects of beetroot juice supplementation on cardiorespiratory endurance in athletes. A systematic review. Nutrients. 2017; 9(1):43.

44 Larsen FJ, Weitzberg E, Lundberg JO, Ekblom B. Effects of dietary nitrate on oxygen cost during exercise. Acta Physiol. 2007;191(1): 59-66.

45 Nyakayiru J, Jonvik KL, Trommelen J, Pinckaers PJ, Senden JM, van Loon LJ, et al. Beetroot juice supplementation improves highintensity intermittent type exercise performance in trained soccer players. Nutrients. 2017;9(3):314.
46 Thompson C, Vanhatalo A, Jell H, Fulford J, Carter J, Nyman L, et al. Dietary nitrate supplementation improves sprint and high-intensity intermittent running performance. Nitric Oxide. 2016;61(3):55-61.

47 Cuenca E, Jodra P, Pérez-López A, GonzálezRodríguez LG, Fernandes da Silva S, VeigaHerreros P, et al. Effects of beetroot juice supplementation on performance and fatigue in a 30-s all-out sprint exercise: a randomized, double-blind cross-over study. Nutrients. 2018;10(9):1222.

48 Wylie LJ, Mohr M, Krustrup P, Jackman SR, Ermıdis G, Kelly J, et al. Dietary nitrate supplementation improves team sport-specific intense intermittent exercise performance. Eur J Appl Physiol. 2013;113(7):1673-84.

49 Jo E, Fischer M, Auslander AT, Beigarten A, Daggy B, Hansen K, et al. The effects of multiday vs. single pre-exercise nitrate supplement dosing on simulated cycling time trial performance and skeletal muscle oxygenation. J Strength Cond Res. 2019;33(1):217-24.

50 Lim ZIX, Singh A, Leow ZZX, Arthur PG, Fournier PA. The effect of acute taurine ingestion on human maximal voluntary muscle contraction. Med Sci Sports Exerc. 2018; 50(2):344-52.

51 Wen C, Li F, Zhang L, Duan Y, Guo Q, Wang $\mathrm{W}$, et al. Taurine is involved in energy metabolism in muscles, adipose tissue, and the liver. Mol Nutr Food Res. 2019;63(2): e1800536-28.

52 Ra SG, Akazawa N, Choi Y, Matsubara T, Oikawa S, Kumagai H, et al. Taurine supplementation reduces eccentric exercise-induced delayed onset muscle soreness in young Men. Adv Exp Med Biol. 2015;803:765-72.

53 Waldron M, Patterson SD, Tallent J, Jeffries $\mathrm{O}$. The effects of oral taurine on resting blood pressure in humans: a meta-analysis. Curr Hypertens Rep. 2018;20(9):81.

54 Kowsari E, Moosavi ZA, Rahimi A, Faramarzi M, Haghighi MM. The effect of short-term taurine amino acid supplement on neuromuscular fatigue, serum lactate level and choice reaction time after maximal athletic performance. J Res Med Dent Sci. 2018;6(1):358-64.

55 Batitucci G, Terrazas SIBM, Nóbrega MP, Carvalho FGd., Papoti M, Marchini JS, et al. Effects of taurine supplementation in elite swimmers performance. Motriz Rev Educ Fis. 2018;24(1):1-7.

56 McLeay Y, Stannard S, Barnes M. The effect of taurine on the recovery from eccentric exercise-induced muscle damage in males. Antioxidants. 2017;6(4):79.

57 da Silva LA, Tromm CB, Bom KF, Mariano I, Pozzi B, da Rosa GL, et al. Effects of taurine supplementation following eccentric exercise in young adults. Appl Physiol Nutr Metab. 2013;39(1):101-4.

58 Warnock R WM, Jeffries O, Patterson S. The effects of caffeine, taurine or caffeine-taurine co-ingestion on repeat-sprint cycling performance and physiological responses. Int $J$ Sports Physiol Perform. 2017;12(10):1341-7. 
59 de Carvalho MB, Brandao CFC, Fassini PG, Bianco TM, Batitucci G, Galan BSM, et al. Taurine supplementation increases post-exercise lipid oxidation at moderate intensity in fasted healthy males. Nutrients. 2020;12(5): 1540.

60 Waldron M, Patterson SD, Jeffries O. Oral taurine improves critical power and severeintensity exercise tolerance. Amino Acids. 2019;51(10-12):1433-41.

61 Figueroa A, Wong A, Jaime SJ, Gonzales JU. Influence of L-citrulline and watermelon supplementation on vascular function and exercise performance. Curr Opin Clin Nutr Metab Care. 2017;20(1):92-8.

62 Martínez-Sánchez A, Ramos-Campo DJ, Fernández-Lobato B, Rubio-Arias JA, Alacid F, Aguayo E. Biochemical, physiological, and performance response of a functional watermelon juice enriched in L-citrulline during a half-marathon race. Food Nutr Res. 2017; 61(1):1330098.
63 Suzuki T, Morita M, Kobayashi Y, Kamimura A. Oral L-citrulline supplementation enhances cycling time trial performance in healthy trained men: double-blind randomized placebo-controlled 2-way crossover study. J Int Soc Sports Nutr. 2016;13(1):6-9.

64 Suzuki I, Sakuraba K, Horiike T, Kishi T, Yabe J, Suzuki T, et al. A combination of oral l-citrulline and 1 -arginine improved 10 -min fullpower cycling test performance in male collegiate soccer players: a randomized crossover trial. Eur J Appl Physiol. 2019;119(5):107584.

65 Cunniffe B, Papageorgiou M, O’Brien B, Davies NA, Grimble GK, Cardinale M. Acute citrulline-malate supplementation and highintensity cycling performance. J Strength Cond Res. 2016;30(9):2638-47.

66 Gonzalez AM, Spitz RW, Ghigiarelli JJ, Sell KM, Mangine GT. Acute effect of citrulline malate supplementation on upper-body resistance exercise performance in recreationally resistance-trained men. J. Strength Cond Res. 2018;32(11):3088-94.
67 A Mor, T Atan, SA Agaoglu, M Ayyildiz. "Effect of arginine supplementation on footballers' anaerobic performance and recovery." 2018;20;104-12.

68 Streeter DM, Trautman KA, Bennett TW, McIntosh LE, Grier JW, Stastny SN, et al. "Endothelial, cardiovascular, and performance responses to $\mathrm{L}$-arginine intake and resistance exercise." no. 9. 2019. Available from: http:// www.intjexersci.com.

69 Pahlavani N, Entezari MH, Nasiri M, Miri A, Rezaie M, Bagheri-Bidakhavidi M, et al. The effect of L-arginine supplementation on body composition and performance in male athletes: a double-blinded randomized clinical trial. Eur J Clin Nutr. 2017;71(4):1028-8.

70 Yaman H, Sönmez GT, Gürel K. "Effects of oral L-arginine supplementation on vasodilation and $\mathrm{VO} 2 \mathrm{max}$ in male soccer players." Biomed Hum Kinet. 2010. 